\title{
Nutrient composition, total phenolic content, and antioxidant activity of tropical Kundasang-grown cucumber at two growth stages
}

\author{
Amir Husni Mohd Shariff ${ }^{*}$, Puteri Noor Zulaikha Megat Mohamed Abdul Wahab ${ }^{1}$, \\ Aanada H. Jahurul ${ }^{1}$, Nurul Huda ${ }^{1}$, Nissha Bharrathi Romes ${ }^{2}$, Mona Zakaria ${ }^{3}$, \\ Jumardi Roslan ${ }^{1}$, Roswanira Abdul Wahab ${ }^{2}$, and Fahrul Huyop ${ }^{2}$ \\ ${ }^{1}$ Universiti Malaysia Sabah, Faculty of Food Science and Nutrition, Jalan UMS, 88400 Kota Kinabalu, Malaysia.
"Corresponding author (amir.husni@ ums.edu.my).
${ }^{2}$ Universiti Teknologi Malaysia, Faculty of Science, 81310 Skudai, Johor Bahru, Malaysia.
'International Islamic University, Centre for Language and Pre-University Academic Development, Kuantan Campus, 25200 ,
Pahang, Malaysia.
}

Received: 28 September 2020; Accepted: 26 November 2020; doi:10.4067/S0718-58392021000200220

\begin{abstract}
The cucumber (Cucumis sativus L.) contains a significant amount of antioxidants, especially when harvested at the right time. The present study evaluated differences in nutrients, total phenolic content, and antioxidant activity of cucumbers grown in Kundasang, Malaysia, at the semi-ripe fruit (SR) and ripe fruit (R) maturation stages. Independent T-tests revealed significant differences $(\mathrm{p}<0.05)$ between proximate analysis data for the $\mathrm{SR}$ and $\mathrm{R}$ stages. Moisture content at the SR stage $(98.217 \pm 0.068 \%)$ was higher than for $\mathrm{R}(97.617 \pm 0.221 \%)$; similar differences were observed for the carbohydrate content (SR: $0.660 \pm 0.027 \%, \mathrm{R}: 0.416 \pm 0.213 \%)$. The crude fiber (SR: $0.320 \pm 0.012 \%, \mathrm{R}: 0.576 \pm$ $0.083 \%$ ), crude fat (SR: $0.039 \pm 0.004 \%, \mathrm{R}: 0.317 \pm 0.019 \%)$, ash (SR: $0.422 \pm 0.366 \%$ ), and crude protein (SR: $0.418 \pm$ $0.018 \%, \mathrm{R}: 0.651 \pm 0.069 \%)$ contents showed that the results for the R stage were greater than for SR. Individual elements in the SR and R fruit significantly differ ( $\mathrm{p}<0.05)$, except for Se. However, Mo was undetected at both maturation stages. Results revealed that the $\mathrm{R}$ stage had a higher mineral content (mg $\left.100 \mathrm{~g}^{-1}\right)$ for Ca (SR: $\left.10.311 \pm 0.096, \mathrm{R}: 14.076 \pm 0.094\right)$, $\mathrm{Mg}(\mathrm{SR}: 8.334 \pm 0.088, \mathrm{R}: 13.354 \pm 0.089), \mathrm{Al}(\mathrm{SR}: 0.468 \pm 0.009, \mathrm{R}: 1.746 \pm 0.019)$, and Fe (SR: $0.127 \pm 0.002, \mathrm{R}: 0.280$ \pm 0.002 ), whereas the SR stage had a lower $\mathrm{Cu}$ content (SR: $0.037 \pm 0, \mathrm{R}: 0.058 \pm 0$ ). The phenolic content (mg g $\left.{ }^{-1} \mathrm{GAE}\right)$ at the SR stage $(352.683 \pm 33.240)$ was higher than at the R stage $(155.691 \pm 17.042)$, and it was inversely correlated with their antioxidant activity, which was expressed in half maximal inhibitory concentration $\left(\mathrm{IC}_{50}, \mu \mathrm{g} \mathrm{mL}^{-1}\right)\left(\mathrm{SR}^{-182.247}\right.$ \pm 9.216 , R: $160.782 \pm 6.741)$. Hence, the nutritional benefits of cucumbers grown in Kundasang are enhanced when harvested between the SR and $\mathrm{R}$ maturation stages.
\end{abstract}

Key words: Cucumis sativus, maturation stage, minerals, nutrition, proximate analysis, total phenolic content.

\section{INTRODUCTION}

The benefits of antioxidants and their extraordinary ability to slow the aging process have been evidently marketed over time by the cosmetic and food industries. Fruit, vegetable, and even chocolate are rich in antioxidants, and the protective mechanism of these compounds revolve around the balance between the antagonist free radicals and the protagonist antioxidants in the human body. When quenching does not occur, free radicals steal electrons from stable biological molecules, consequently propagating an oxidative chain reaction in adjacent cells. This can result in an unhealthy state of imbalance known as oxidative stress. An increase in oxidative stress has been linked to diseases such as arthritis, 
premature aging, and cancer susceptibility (García-González et al., 2015; Aksoy et al., 2017). Fortunately, the destructive effect of free radicals in our body can be counteracted by consuming various antioxidants. There is convincing evidence that antioxidants can decelerate the aging process and inhibit the progression of cancer cells (Chen et al., 2018).

The literature has shown that cucumber (Cucumis sativus L.) can contain a significant amount of antioxidants (Chen et al., 2018). It is a member of the Cucurbitaceae family, which includes melon, pumpkin, and squash. The fruit has a high water content but is low in calories. It is believed that the cucumber possesses antidiabetic, lipid-lowering, and antioxidant activity (Chen et al., 2018). The cucumber is a promising and possibly cost-effective source of antioxidants because it is a common fruit cultivated in abundance worldwide. The cucumber is a food source and cheap ingredient in salads, but its use as a reservoir of powerful anti-aging compounds has been apparently overlooked. However, to what extent does the fruit conceal the target compounds and at what maturation stages are the compounds most abundant? These questions warrant a scientific explanation so that the cucumber can be harvested at the right maturation stage. Recent studies have shown that the antioxidant and phenolic contents in fruit fluctuate, depending on the ripening stage and cultivar (Dong et al., 2019). The global antioxidant market is predicted to expand at a compound annual growth rate (CAGR) of $4.5 \%$, and will reach 5.7 billion USD by 2027; the Asia-Pacific region exhibited the most prominent market growth in 2018, and the CAGR is expected to expand more than 5\% between 2019 and 2027 (Transparency Market Research, 2020).

The present research aimed to quantify the antioxidant activity, phenolic compounds, and nutritive value of $C$. sativus at two stages of maturation in Kundasang, Sabah, Malaysia. This location was chosen because it is the largest commercial vegetable farming community in the state of Sabah, and the mild highland climate promotes healthy crop development. This highlights the potential of cucumbers in the effective treatment or prevention of oxidative stress. Recording the nutrient content of $C$. sativus at the two maturation stages could be useful in identifying the ideal stage in which phenolics can be harvested from the fruit in the form of potent natural antioxidants. This knowledge is useful for the optimal delivery of antioxidants to the human diet, especially for those who rely on antioxidants to slow cancer and aging (Chen et al., 2018). The findings of the antioxidant activity of the fruit lead to possible industrial applications such as cosmetics, pharmaceuticals, and paint. The use of simple crops such as cucumber at industrial scale would also provide an opportunity to develop food products on a large scale. Therefore, quantifying the antioxidant activity of cucumbers offers an alternative to meet the global demand for antioxidants. The objective of the present study was to measure the antioxidative potency of antioxidants in cucumbers at two maturation stages.

\section{MATERIALS AND METHODS}

The main materials used in this study were semi-ripe (SR) and ripe (R) cucumber (Cucumis sativus L.) grown in the

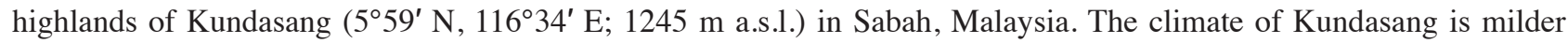
compared to many parts of Malaysia; it has a mean temperature and annual rainfall of $20.5^{\circ} \mathrm{C}$ and $2189 \mathrm{~mm}$, respectively. Methanol, 2,2-diphenyl-1-picrylhydrazyl (DPPH), ascorbic acid, petroleum ether, ethanol, gallic acid, and Folin-Ciocalteu reagent were purchased from Sigma-Aldrich (St. Louis, Missouri, USA). Potassium sulphate $\left(\mathrm{K}_{2} \mathrm{SO}_{4}\right)$, copper sulphate $\left(\mathrm{CuSO}_{4}\right)$, sulphuric acid $\left(\mathrm{H}_{2} \mathrm{SO}_{4}\right)$, sodium hydroxide $(\mathrm{NaOH})$, boric acid $\left(\mathrm{H}_{3} \mathrm{BO}_{3}\right)$, hydrochloric acid $(\mathrm{HCl})$, nitric acid $\left(\mathrm{HNO}_{3}\right)$, and hydrogen peroxide $\left(\mathrm{H}_{2} \mathrm{O}_{2}\right)$ were purchased from Merck (Darmstadt, Germany). All the chemicals used in this study were of analytical grade.

\section{Sampling method}

Sampling was done using a completely randomized design method to ensure representative results, and all samples were collected on the same day in September 2019. Cucumbers were divided into two groups of 12 cucumbers each from the SR and R stages, respectively; each group was further divided into three subgroups. The R cucumbers were harvested 10 wk from anthesis (Qian et al., 2013), while SR cucumbers were collected after 5 wk.

\section{Sample preparation and extraction}

Cucumber samples were weighed and cleaned with distilled water, and a portion of them was sliced and left in the drying cabinet at $40^{\circ} \mathrm{C}$ for $1 \mathrm{wk}$ until dried and crisp. The composite mass of the dried cucumbers was recorded, and the samples were ground into a fine powder. These samples were used for mineral, phenolic, and antioxidant activity analyses, which 
required further processing by methanolic extraction. The rest of the fruits were stored at $4{ }^{\circ} \mathrm{C}$ for proximate analysis and analyzed on a wet basis. The powdered samples $(50 \mathrm{~g})$ were soaked in methanol $(1 \mathrm{~L})$ for $2 \mathrm{~d}$ at room temperature in the dark. Samples were filtered through a Whatman $\mathrm{Nr} 1$ filter paper, and the filtrates were vacuum evaporated at $40{ }^{\circ} \mathrm{C}$ to $\sim 50 \mathrm{~mL}$. The $C$. sativus concentrate was lyophilized to provide a viscous consistency, transferred into screw-capped bottles, and stored at $-20{ }^{\circ} \mathrm{C}$ until further use.

\section{Crude protein and crude fat content}

The Kjedahl method (AOAC, 2010) was used to quantify the crude protein content. The sample was wet digested to release $\mathrm{N}$ for quantification by an appropriate titration method. The protein content was calculated by Equation 1:

$$
\text { Protein content }(\%)=(\mathrm{a} \times \mathrm{b} \times 14.0 \times 6.25 \times 100 \%) /(\mathrm{c} \times 1000)
$$

where a is the volume of $\mathrm{HCl}(\mathrm{mL}), \mathrm{b}$ is the normality of $\mathrm{HCl}(\mathrm{N})$, and $\mathrm{c}$ is the sample mass $(\mathrm{g})$.

The Soxhlet extraction method (AOAC, 2010) was used to quantify the crude fat content in the sample with a solvent extraction system (Soxtec 2050, FOSS, Hillerød, Denmark). This sample was heated at $105^{\circ} \mathrm{C}$ for 30 min until a constant mass was reached. The fat content was calculated by Equation 2:

$$
\text { Fat content }(\%)=[(b-a) / c] \times 100 \%
$$

where $\mathrm{a}$ is the mass of the extraction cup $(\mathrm{g}), \mathrm{b}$ is the mass of the extraction cup + sample $(\mathrm{g})$, and $\mathrm{c}$ is the sample mass $(\mathrm{g})$.

\section{Crude fiber and ash content}

The FibreBag filtration method was used to determine the crude fiber content of the sample with the FIBRETHERM instrument (C. Gerhardt GmbH \& Co. KG, Königswinter, Germany). This treatment dissolved carbohydrates, proteins, and fats from the sample to produce the crude fiber content (AOAC, 2010). The crude fiber content was calculated by Equation 3 :

$$
\text { Crude fiber content }(\%)=\{[(\mathrm{m} 3-\mathrm{m} 1)-(\mathrm{m} 4-\mathrm{m} 5)] / 2\} \times 100 \%
$$

where $\mathrm{m} 1$ is the mass of the FibreBag (g), $\mathrm{m} 2$ is the mass of FibreBag + sample (g), $\mathrm{m} 3$ is crucible mass after the oven treatment $(\mathrm{g}), \mathrm{m} 4$ is crucible mass after the furnace treatment $(\mathrm{g})$, and $\mathrm{m} 5$ is the mass of the empty FibreBag after ashing $(\mathrm{g})$.

The ash content was estimated according to the AOAC (2010) in which the sample was oxidized in a furnace at $550{ }^{\circ} \mathrm{C}$. The remaining residues were weighed, and the ash content was determined according to Equation 4 :

$$
\text { Ash content }(\%)=[(w 3-w 1)-(w 2-w 1)] \times 100 \%
$$

where w1 is crucible mass $(\mathrm{g})$, w2 is crucible mass $(\mathrm{g})+$ sample before ashing $(\mathrm{g})$, and w3 is crucible mass $(\mathrm{g})+$ sample after ashing (g).

\section{Moisture content}

The moisture content was determined by the conventional oven method described by the AOAC (2010). The sample was placed in an oven overnight before the final mass was recorded, and moisture content was estimated by the following formula (Equation 5):

$$
\text { Moisture content }(\%)=[(b-c) /(b-a)] \times 100 \%
$$

where A is crucible mass (g), B is crucible mass + sample (g), C is crucible mass + sample after overnight oven treatment $(\mathrm{g})$.

\section{Carbohydrate and total phenolic content}

The carbohydrate content of each sample was quantified by adding the protein, fat, moisture, ash, and crude fiber contents. The total was subtracted from $100 \%$ to obtain the carbohydrate content (Equation 6):

$$
\text { Carbohydrate content }(\%)=100 \%-(\mathrm{A}+\mathrm{B}+\mathrm{C}+\mathrm{D}+\mathrm{E})
$$

where $\mathrm{A}$ is protein content (\%), $\mathrm{B}$ is fat content $(\%), \mathrm{C}$ is moisture content $(\%), \mathrm{D}$ is ash content $(\%)$, and $\mathrm{E}$ is crude fiber content (\%).

The total phenolic content (TFC) of each sample was estimated by the Folin-Ciocalteu method. Each sample was diluted in distilled water to a concentration of $0.4 \mathrm{mg} \mathrm{mL}^{-1}$, and a $0.5 \mathrm{~mL}$ aliquot of the sample was mixed with $0.5 \mathrm{~mL}$ Folin reagent and $1.0 \mathrm{~mL}$ distilled water. The mixture was left to stand for 2 to $5 \mathrm{~min}$ before $0.5 \mathrm{~mL}$ sodium carbonate $(10 \%, \mathrm{w} / \mathrm{v})$ was added and the mixture was incubated for $1 \mathrm{~h}$ at room temperature. Sample absorbance was read at $760 \mathrm{~nm}$ with a UV-Vis spectrophotometer using distilled water as the blank. The standard curve was prepared at different gallic 
acid concentrations $\left(0.06,0.08,0.10\right.$, and $\left.0.12 \mathrm{mg} \mathrm{mL}^{-1}\right)$ dissolved in distilled water. Values were expressed as milligram of gallic acid equivalents (mg GAE $\mathrm{g}^{-1}$ extract) as shown in Equation 7:

$$
\mathrm{C}=\mathrm{cV} / \mathrm{m}
$$

where $\mathrm{C}$ is total phenolic content $\left(\mathrm{mg} \mathrm{g}^{-1}\right)$ of extract in $\mathrm{GAE}, \mathrm{c}$ is gallic acid concentration from the standard calibration curve $\left(\mathrm{mg} \mathrm{mL}^{-1}\right), \mathrm{V}$ is extract volume $(\mathrm{mL})$, and $\mathrm{m}$ is extract mass $(\mathrm{m})$.

\section{Mineral composition}

The mineral composition of each sample was analyzed according to the AOAC (2010) procedure. Each sample was weighed to $3 \mathrm{~g}$ and heated in the furnace at $550{ }^{\circ} \mathrm{C}$ overnight; the sample was then digested in $3 \mathrm{~mL}$ nitric acid and 5 $\mathrm{mL}$ hydrochloric acid until the solution became clear. The sample was filtered through a Whatman PTFE filter $(0.45 \mu \mathrm{m})$ before inductively coupled plasma optical emission spectroscopy (ICP-OES) analysis. The instrument was calibrated with a three-point calibration standard $(0.1,0.5$, and $1.0 \mathrm{ppm})$. Each sample was analyzed in triplicate.

\section{Data analyses}

Data analyses were performed with the SPSS version 24 (IBM, Armonk, New York, USA) and Origin software (OriginLab Corporation, Northampton, Massachusetts, USA) in which $\mathrm{p}<0.05$ was considered significant. One-sample t-tests with two-tailed distribution were used to compare the means for the two cucumber maturation stages.

\section{RESULTS AND DISCUSSION}

\section{Proximate analysis}

The results of the proximate analysis on the SR and R cucumbers are tabulated in Table 1. Moisture contents between the SR and R cucumbers were significantly different $(\mathrm{p}<0.05)$ with values of $98.22 \pm 0.07 \%$ and $97.62 \pm 0.22 \%$, respectively. Our results are consistent for cucumbers growing in regions with high relative humidity (Abbey et al., 2017), which is the case in Kundasang, Sabah. In addition, SR and R cucumbers were cultivated in a polyhouse setup, which promoted higher moisture content than cucumbers grown in the open field (Abbey et al., 2017).

The crude fiber content $(0.32 \pm 0.01 \%)$ for cucumbers at the $\mathrm{R}$ stage was well within reported values, but not so for the SR stage $(0.58 \pm 0.08 \%)$. Crude fiber content usually tends to decrease as the fruit ripens, except for saba bananas. The crude fiber content of the crop decreased during the middle maturation stage and increased again at the $\mathrm{R}$ stage. Therefore, a general statement that crude fiber decreases over time is not adequate because it is not true for some fruit. The present study revealed that crude fiber content increased with maturation and reached the mean values reported in previous studies. The R cucumbers required a higher shear force during the comminution process because of a higher content of crystalline cellulose micelles (Abbey et al., 2017; Cárdenas-Pérez et al., 2018). The crude fat value in SR cucumbers $(0.04 \pm 0.00 \%)$ was significantly low $(\mathrm{p}<0.05)$ compared with R cucumbers $(0.32 \pm 0.02 \%)$. A higher fat content can be attributed to the higher seed composition in SR than in R cucumbers, given that fats such as linoleic, stearic, and myristic acids also exist in seeds (Ngure et al., 2015). It is important to note that a higher ash content was associated with more minerals. The SR $(0.35 \pm 0.01 \%)$ and $\mathrm{R}(0.42 \pm 0.04 \%)$ cucumbers provided mean ash contents similar to those reported in the literature (Abbey et al., 2017), although higher contents between $0.59 \%$ and $0.69 \%$ have been reported (Essien et al., 2016; Abbey et al., 2017). This discrepancy between our findings and those reported in the literature can be attributed to varying growing conditions, time, and genotypical factors (Milosevic and Milosevic, 2012).

Table 1. Proximate analysis of semi-ripe and ripe cucumbers.

\begin{tabular}{lrr}
\hline Proximate content & \multicolumn{1}{c}{ Semi-ripe } & \multicolumn{1}{c}{ Ripe } \\
\cline { 2 - 3 } Moisture & $98.22 \pm 0.07 \mathrm{a}$ & \\
Crude fiber & $0.32 \pm 0.01 \mathrm{~b}$ & $97.62 \pm 0.22 \mathrm{~b}$ \\
Crude fat & $0.04 \pm 0.00 \mathrm{~b}$ & $0.58 \pm 0.08 \mathrm{a}$ \\
Ash & $0.35 \pm 0.01 \mathrm{~b}$ & $0.32 \pm 0.02 \mathrm{a}$ \\
Crude protein & $0.42 \pm 0.02 \mathrm{~b}$ & $0.42 \pm 0.04 \mathrm{a}$ \\
Carbohydrates & $0.66 \pm 0.03 \mathrm{a}$ & $0.65 \pm 0.07 \mathrm{a}$ \\
\hline
\end{tabular}

Means ( \pm standard deviation) with different letters in the same row are significantly different at $\mathrm{p}<0.05$. 
Our study found a significant difference in cucumber crude protein content at the two maturation stages, which showed an upward trend as the fruit ripened. The crude protein content $(0.42 \pm 0.02 \%)$ at the SR stage was lower than at the R stage $(0.65 \pm 0.07 \%)(\mathrm{p}<0.05)$. A higher protein content was typical of an increased protein expression due to cell wall modification, pigmentation, and enhanced oxidative stress in the $\mathrm{R}$ cucumbers, all of which occur in the tissues during ripening. Meanwhile, carbohydrate values in the SR $(0.66 \pm 0.03)$ and $\mathrm{R}(0.42 \pm 0.02)$ cucumbers were different compared with the literature (Essien et al., 2016), which was likely because of the high moisture content in the SR and R cucumbers; in addition, the studies could have described different species, cultivars, and genotypes. Conversely, the R cucumbers showed a lower mean carbohydrate content because they were enzymatically converted to form the fruit (Essien et al., 2016).

\section{Mineral analysis}

Results revealed significant differences in the mineral composition of SR and R cucumbers (Table 2). The exceptions were Mo and Se, which were found at low concentrations, particulary Se. Calcium was detected at values that were lower than

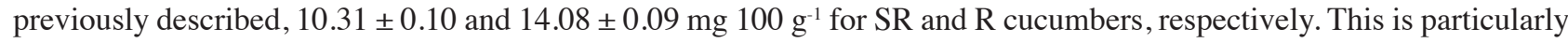
important because $99 \%$ of $\mathrm{Ca}$ deposits are found in bones, and it is the most abundant mineral in the human body. The literature has shown that $\mathrm{Ca}$ build-up in fruit can vary according to transpiration and growth levels. In contrast, mineral dissemination to the fruit predominantly occurs through the xylem and much less by the phloem. However, Hocking et al. (2016) indicated that the lower than average Ca content in SR and R cucumbers tested in this study was likely due to the poor mobility of $\mathrm{Ca}$ ions through the phloem that caused localized $\mathrm{Ca}$ deficiencies in the fruit.

The concentrations of $\mathrm{Mg}$ and water in soils are believed to be high in well-irrigated regions (Qadir et al., 2018). This explains the higher Mg content in the SR and R cucumbers because they are grown in the relatively well-irrigated Kundasang region. The Mg concentrations increased over time, $8.66 \pm 0.09$ and $13.354 \pm 0.09 \mathrm{mg} 100 \mathrm{~g}^{-1}$ for the SR and $\mathrm{R}$ cucumbers, respectively. These values were similar to those described in earlier studies (Abbey et al., 2017). Moreover, the higher $\mathrm{Mg}$ content in the $\mathrm{R}$ cucumbers correlated with a larger fruit size and its accumulation in the cell walls during maturation. A delayed cucumber harvest in the Kundasang region could ensure a higher Mg content. This mineral plays a vital role as a cofactor in over 300 enzyme systems in the human body. Its functions include nerve function, protein synthesis, cardiac excitability, alleviating migraine, Alzheimer's disease, and stroke in patients (Volpe, 2013). A low dietary intake of $\mathrm{Mg}$ has been associated with insulin resistance in apparently healthy adults, as well as aggravated cataracts (Agarwal et al., 2012).

According to the European Food Safety Authority, an acceptable weekly intake of Al is $1 \mathrm{mg} \mathrm{kg}^{-1}$ body weight, beyond which the toxicity of the mineral toward humans increases. While $\mathrm{Al}$ occurs naturally in soil, water, and air, high levels of this mineral in the environment are the result of mining or the processing of $\mathrm{Al}$ ores and the manufacture of $\mathrm{Al}$ metal, alloys, and compounds (Kraus et al., 2006). The Al content in cucumbers was elevated during maturation with the SR cucumbers at $0.47 \pm 0.01 \mathrm{mg} 100 \mathrm{~g} \mathrm{~g}^{-1}$ and the R cucumbers with a higher mean of $1.75 \pm 0.02 \mathrm{mg} 100 \mathrm{~g} \mathrm{~g}^{-1}$. An early harvest could be necessary to prevent high $\mathrm{Al}$ uptake because the mineral is pro-oxidant and tends to induce oxidative

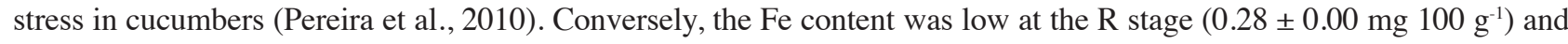

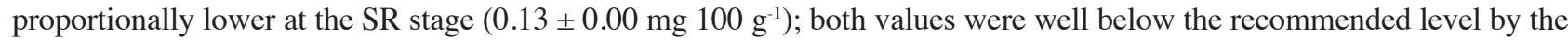

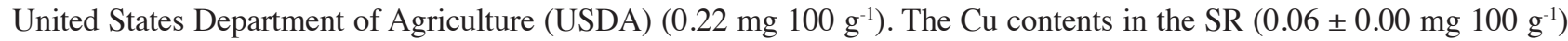
and $\mathrm{R}\left(0.04 \pm 0.00 \mathrm{mg} 100 \mathrm{~g}^{-1}\right)$ cucumbers were also low. Both $\mathrm{Fe}$ and $\mathrm{Cu}$ play roles in chlorophyll synthesis. Hence,

Table 2. Mineral content in semi-ripe and ripe cucumbers.

\begin{tabular}{lcr}
\hline Mineral & Semi-ripe & \multicolumn{1}{c}{ Ripe } \\
\cline { 2 - 2 } Calcium & $10.31 \pm 0.10 \mathrm{~b}$ & \\
Magnesium $100 \mathrm{~g}^{-1}$ & $14.08 \pm 0.09 \mathrm{a}$ \\
Aluminum & $8.66 \pm 0.09 \mathrm{~b}$ & $13.354 \pm 0.09 \mathrm{a}$ \\
Iron & $0.47 \pm 0.01 \mathrm{~b}$ & $1.75 \pm 0.02 \mathrm{a}$ \\
Selenium & $0.13 \pm 0.00 \mathrm{~b}$ & $0.28 \pm 0.00 \mathrm{a}$ \\
Copper & ND & Trace \\
Zinc & $0.04 \pm 0.00 \mathrm{~b}$ & $0.06 \pm 0.00 \mathrm{a}$ \\
Sodium & $0.24 \pm 0.00 \mathrm{a}$ & $0.19 \pm 0.00 \mathrm{~b}$ \\
Molybdenum & $2.27 \pm 0.03 \mathrm{~b}$ & $6.01 \pm 0.05 \mathrm{a}$ \\
Phosphorus & ND & ND \\
& $31.84 \pm 0.04 \mathrm{a}$ & $24.67 \pm 0.02 \mathrm{~b}$ \\
\hline
\end{tabular}

ND: Not detected. Means ( \pm standard deviation) with different letters in the same row are significantly different at $\mathrm{p}<0.05$. 
cucumbers grown in the Kundasang region are characteristically poor in $\mathrm{Fe}$ and $\mathrm{Cu}$, which is likely due to their low concentration in the soil.

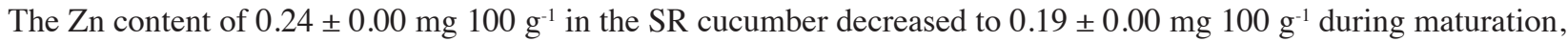
which showed a similar trend to earlier findings (Hong et al., 2016). The concomitant reduction in Zn content during maturation was consistent with the role of this mineral in the synthesis and metabolism of carbohydrates in plants (Palmer and Guerinot, 2009). This mineral is viewed as a potential anti-tumor agent in cancer treatment (Wiesmann et al., 2018).

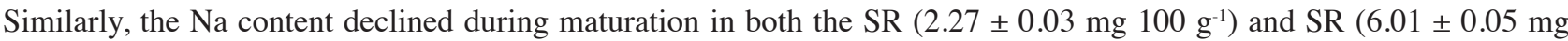
$100 \mathrm{~g}^{-1}$ ) stages but were within USDA requirements. This means that the cucumbers were grown on Na-rich soil, while the mature cucumbers were richer in $\mathrm{Na}$ as a result of a longer time in the ground, which allowed greater uptake (Choe et al., 2015). Finally, the $\mathrm{P}$ content in cucumbers grown in Kundasang exhibited a decreasing trend during maturation with values from $31.84 \pm 0.04$ to $24.67 \pm 0.02 \mathrm{mg} 100 \mathrm{~g}^{-1}$ at the SR stage; however, these values met the $21.0 \mathrm{mg} 100 \mathrm{~g} \mathrm{~g}^{-1}$ requirement stipulated by the USDA. Phosphorus is essential for developing energy, sugars, and nucleic acid in plants, especially at the beginning of fruit growth. This need decreases as the fruit ripens, which explains the reduction of $\mathrm{P}$ in the more mature cucumbers. Phosphorus is relevant for bone development in humans, and it is an essential component of different cell structures, including nucleic acids and cell membranes.

\section{Total phenolic content (TPC)}

The present study found a significant difference in the TPC in cucumbers at the two maturation stages $(\mathrm{p}<0.05)$ (Table 3). The SR and R cucumbers exhibited a decreasing trend in TPC content during maturation with $352.68 \pm 33.24$ and $155.69 \pm 17.04 \mathrm{mg} \mathrm{g}^{-1} \mathrm{GAE}$, respectively; this is consistent with the fact that younger fruits are richer in phenolics than mature fruits (Mphahlele et al., 2014). The TPC value concurred with those described in previous studies. Although cucumbers are known to be rich in phenolics, the TPC of the R cucumbers was comparatively lower than that reported for wheat $\left(106.72 \pm 19.01 \mathrm{mg} \mathrm{g}^{-1} \mathrm{GAE}\right)$. A total of 11 other antioxidants, that is, polyphenols/flavonoids, have been isolated from cucumbers consisting of kaempferol, quercetin, and apigenin (Garcia-Salas et al., 2010). Kaempferol has been found to increase apoptosis in human cervical cancer cells. It helps relieve inflammation in humans, and promotes the biosynthesis of auxins (Rajendran et al., 2014) and gibberellins in plants, which are needed during the cell division and expansion stages of fruit development (Aghofack-Nguemezi and Schwab, 2014).

Meanwhile, the therapeutic effects of quercetin are derived from its ability to reduce oxidative stress and inflammation. The compound also functions to down-regulate pro-inflammatory cytokines to promote wound healing (Hujiahemaiti et al., 2018). Another common flavonoid found in many plants and cucumber is apigenin that is known for its neuroprotective effects. The compound has been clinically proven to reduce inflammation in patients suffering Alzheimer's (Nabavi et al., 2018) and Parkinson's disease (Nabavi et al., 2018). The concentrations of kaempferol, quercetin, and apigenin are subjected to their synthesis by naringenin (Krumbein et al., 2012). Thus, the biosynthesis of such flavonoids in cucumbers was a possible factor in the present study to decrease TPC during maturation.

The TPC of a specimen does not always correctly reflect its antioxidant activity, except specifying the amount of antioxidants. Furthermore, not all phenolics exhibit antioxidant properties and not all antioxidants are active (Karuppagounder et al., 2016). To better understand the relationship between antioxidant activity with respect to the available phenolic compounds in the SR and R cucumbers, another study on antioxidants is necessary.

\section{Determination of antioxidant activity}

The antioxidant activity of the samples was measured by a DPPH assay in which an $\mathrm{IC}_{50}$ value described the concentration that was sufficient to obtain $50 \%$ maximum inhibition. A lower $\mathrm{IC}_{50}$ value therefore indicated greater antioxidant activity. The $\mathrm{IC}_{50}$ value in the $\mathrm{R}$ cucumbers was significantly lower $\left(160.78 \pm 6.74 \mu \mathrm{gL}^{-1}\right)(\mathrm{p}<0.05)$ compared with cucumbers at the SR stage (182.25 $\pm 9.22 \mu \mathrm{g} \mathrm{mL}^{-1}$ ) (Table 4). Despite the lower TPC of cucumbers at the R stage (Table 3), their measured antioxidant activity confirmed the non-antioxidant characteristic of certain phenolics in the fruits. A study by Iloki Assanga et al. (2013) also found that when noni (Morinda citrifolia L.) was grown from May to June, it exhibited weaker antioxidant activity despite a higher TPC value than when it was grown in November. The antioxidant activity of SR and R cucumbers in the present study was substantially higher than findings reported in the literature (1630 to $1680 \mu \mathrm{g} \mathrm{mL}^{-1}$ ). This also concurred with the proportional increase in the antioxidant activity of some fruit, such as red raspberries and noni, during maturation (Iloki Assanga et al., 2013). 
Table 3. Total phenolic content of cucumbers expressed as gallic acid equivalents (GAE).

\begin{tabular}{lcc}
\hline & Semi-ripe & Ripe \\
\hline Total phenolic content, $\mathrm{mg} \mathrm{g}^{-1} \mathrm{GAE}$ & $352.68 \pm 33.24 \mathrm{a}$ & $155.69 \pm 17.04 \mathrm{~b}$ \\
\hline $\begin{array}{l}\text { Means ( } \pm \text { standard deviation) with different letters in the same row are } \\
\text { significantly different at } \mathrm{p}<0.05 \text {. }\end{array}$
\end{tabular}

Table 4. Antioxidant activity in ascorbic acid of semi-ripe and ripe cucumbers.

\begin{tabular}{lccc}
\hline & Semi-ripe & Ripe & Ascorbic acid \\
\hline $\mathrm{IC}_{50}, \mu \mathrm{g} \mathrm{mL}{ }^{-1}$ & $182.25 \pm 9.22 \mathrm{a}$ & $160.78 \pm 6.74 \mathrm{~b}$ & $49.37 \pm 4.07$ \\
\hline
\end{tabular}

Means ( \pm standard deviation) with different letters in the same are significantly different at $\mathrm{p}<0.05 . \mathrm{C}_{50}$ : Half maximal inhibitory concentration.

\section{CONCLUSIONS}

The study revealed significant differences in the nutrient composition of cucumber (Cucumis sativus L.) at two evaluated maturation stages. Cucumbers at the ripe $(\mathrm{R})$ stage exhibited a higher overall proximate composition, except for moisture and carbohydrate contents; they also had higher contents of individual minerals, with the exception of $\mathrm{Zn}$ and P. Both Se and Mo were found in very low concentrations at both maturation stages. Likewise, the two maturation stages exhibited total phenolic content (TPC) in cucumbers that were significantly different $(\mathrm{p}<0.05)$; the semi-ripe (SR) cucumbers recorded a higher TPC mean $\left(352.68 \pm 33.24 \mathrm{mg} \mathrm{g}^{-1} \mathrm{GAE}\right)$ compared with $\mathrm{R}$ cucumbers $\left(155.69 \pm 17.04 \mathrm{mg} \mathrm{g}^{-1} \mathrm{GAE}\right)$. The $\mathrm{R}$ cucumbers showed greater antioxidant activity $\left(\mathrm{IC}_{50}=160.78 \pm 6.74 \mu \mathrm{g} \mathrm{mL^{-1 }}\right)$ than $\mathrm{SR}$ cucumbers $\left(\mathrm{IC}_{50}=182.25\right.$ $\pm 9.22 \mu \mathrm{g} \mathrm{mL}^{-1}$ ), which emphasized the largely non-antioxidant characteristics of certain phenolic compounds in the SR cucumbers. Based on the collective data, it can be inferred that the nutritional benefits of cucumbers grown in Kundasang are enhanced when harvested between the SR and R maturation stages.

\section{ACKNOWLEDGEMENTS}

The authors wish to express their sincere appreciation to the Universiti Malaysia Sabah for their support to conduct research in the field of Food Science and Nutrition.

\section{REFERENCES}

Abbey, B.W., Nwachoko, N., and Ikiroma, G.N. 2017. Nutritional value of cucumber cultivated in three selected states of Nigeria. Biochemistry \& Analytical Biochemistry 6(3):1000328.

Agarwal, R., Iezhitsa, I.,Agarwal, P., and Spasov, A. 2012. Magnesium deficiency: does it have a role to play in cataractogenesis? Experimental Eye Research 101:82-89.

Aghofack-Nguemezi, J., and Schwab, W. 2014. Differential accumulation of flavonoids by tomato (Solanum lycopersicum) fruits tissues during maturation and ripening. Journal of Applied Biosciences 84:7674-7681.

Aksoy, H.M., Kaya, Y., Ozturk, M., Secgin, Z., Onder, H., and Okumus, E. 2017. Pseudomonas putida-induced response in phenolic profile of tomato seedlings (Solanum lycopersicum L.) infected by Clavibacter michiganensis subsp. michiganensis. Biological Control 105:6-12.

AOAC. 2010. Official methods of analysis of AOAC international. $18^{\text {th }}$ ed. Association of Official Analytical Chemists (AOAC) International, Gaithersburg, Maryland, USA.

Cárdenas-Pérez, S., Chanona-Pérez, J.J., Güemes-Vera, N., Cybulska, J., Szymanska-Chargot, M., Chylinska, M., et al. 2018. Structural, mechanical and enzymatic study of pectin and cellulose during mango ripening. Carbohydrate Polymers 196:313-321.

Chen, L., Huang, G., and Hu, J. 2018. Preparation, deproteinization, characterisation, and antioxidant activity of polysaccharide from cucumber (Cucumis sativus L.) International Journal of Biological Macromolecules 108:408-411.

Choe, K.Y., Han, S.Y., Gaub, P., Shell, B., Voisin, D.L., Knapp, B.A., et al. 2015. High salt intake increases blood pressure via BDNF-mediated downregulation of KCC2 and impaired baroreflex inhibition of vasopressin neurons. Neuron 85(3):549-560. 
Dong, X., Hu, Y., Li, Y., and Zhou, Z. 2019. The maturity degree, phenolic compounds and antioxidant activity of Eureka lemon [Citrus limon (L.) Burm. f.]: A negative correlation between total phenolic content, antioxidant capacity and soluble solid content. Scientia Horticulturae 243:281-289.

Essien, A.D., Ogbonna, O.J., Abe, P.N., Nnaoma, I.E,. and Omoregha, C.U. 2016. Comparative studies of the phytochemistry, proximate analysis, mineral and vitamin compositions of the methanol leaf extracts of Cucumis sativus L. and Daucus carota L. International Journal of Pharmacological Research 6(8):282-285.

García-González, A., Gaxiola-Robles, R., and Zenteno-Savín, T. 2015. Oxidative stress in patients with rheumatoid arthritis. Revista de Investigacion Clinica 67:46-53.

Garcia-Salas, P., Morales-Soto, A., Segura-Carretero, A., and Fernández-Gutiérrez, A. 2010. Phenolic-compound-extraction systems for fruit and vegetable samples. Molecules 15:8813-8826.

Hocking, B., Tyerman, S.D., Burton, R.A., and Gilliham, M. 2016. Fruit calcium: Transport and physiology. Frontiers in Plant Science 7:1-17.

Hong, J., Wang, L., Sun, Y., Zhao, L., Niu, G., Tan, W., et al. 2016. Foliar applied nanoscale and microscale $\mathrm{CeO}_{2}$ and $\mathrm{CuO}$ alter cucumber (Cucumis sativus) fruit quality. Science of the Total Environment 563-564:904-911.

Hujiahemaiti, M., Sun, X., Zhou, J., Lv, H., Li, X., et al. 2018. Effects of quercetin on human oral keratinocytes during re-epithelialization: An in vitro study. Archives of Oral Biology 95:187-194.

Iloki Assanga, S.B., Lewis Luján, L.M., Rivera-Castañeda, E.G., Gil-Salido, A.A., Acosta-Silva, A.L., Meza-Cueto, C.Y., et al. 2013. Effect of maturity and harvest season on antioxidant activity, phenolic compounds and ascorbic acid of Morinda citrifolia L. (noni) grown in Mexico (with track change). African Journal of Biotechnology 12(29):4630-4639.

Karuppagounder, V., Arumugam, S., Thandavarayan, R.A., Sreedhar, R., Giridharan, V.V., and Watanabe, K. 2016. Molecular targets of quercetin with anti-inflammatory properties in atopic dermatitis. Drug Discovery Today 21:632-639.

Kraus, T., Schaller, K.H., Angerer, J., Hilgers, R.D., and Letzel, S. 2006. Aluminosis - Detection of an almost forgotten disease with HRCT. Journal of Occupational Medicine and Toxicology 1:1-9.

Krumbein, A., Saeger-Fink, H., and Schonhof, I. 2012. Changes in quercetin and kaempferol concentrations during broccoli head ontogeny in three broccoli cultivars. Journal of Applied Botany and Food Quality 81:136-139.

Milosevic, T., and Milosevic, N. 2012. Factors influencing mineral composition of plum fruits. Journal of Elementology 17:453-464.

Mphahlele, R.R., Stander, M.A., Fawole, O.A., and Opara, U.L. 2014. Effect of fruit maturity and growing location on the postharvest contents of flavonoids, phenolic acids, vitamin $\mathrm{C}$ and antioxidant activity of pomegranate juice (cv. Wonderful). Scientia Horticulturae 179:36-45.

Nabavi, S.F., Khan, H., D’onofrio, G., Šamec, D., Shirooie, S., Dehpour, A.R., et al. 2018. Apigenin as neuroprotective agent: Of mice and men. Pharmacological Research 128:359-365.

Ngure, J.W., Cheng, C., Yang, S., Lou, Q., Li, J., Qian, C., et al. 2015. Cultivar and seasonal effects on seed oil content and fatty acid composition of cucumber as a potential industrial crop. Journal of the American Society for Horticultural Science 140(4):362-372.

Palmer, C.M., and Guerinot, M.L. 2009. Facing the challenges of $\mathrm{Cu}$, Fe and Zn homeostasis in plants. Nature Chemical Biology 5(5):333-340.

Pereira, L.B., Mazzanti, C.M., Gonçalves, J.F., Cargnelutti, D., Tabaldi, L.A., Becker, A.G., et al. 2010. Aluminum-induced oxidative stress in cucumber. Plant Physiology and Biochemistry 48:683-689.

Qadir, M., Schubert, S., Oster, J.D., Sposito, G., Minhas, P.S., Cheraghi, S.A.M., et al. 2018. High-magnesium waters and soils: Emerging environmental and food security constraints. Science of the Total Environment 642:1108-1117. https://doi.org/10.1016/j.scitotenv.2018.06.090.

Qian, C., Mi, H., Zhao, Y., He, Z., and Mao, L. 2013. Effect of maturity stage on the gene expression of antioxidative enzymes in cucumber (Cucumis sativus L.) fruits under chilling stress. Journal of Integrative Agriculture 12:1495-1500.

Rajendran, P., Rengarajan, T., Nandakumar, N., Palaniswami, R., Nishigaki, Y., and Nishigaki, I. 2014. Kaempferol, a potential cytostatic and cure for inflammatory disorders. European Journal of Medicinal Chemistry 86:103-112.

Transparency Market Research. 2020. Antioxidants market insights, trends and growth outlook. In Chemicals \& Materials. Market Research Report. Transparency Market Research, Pune, Maharashtra, India.

Volpe, S.L. 2013. Magnesium in disease prevention and overall health. Advances in Nutrition 4(3):378S-383S. https://doi.org/10.3945/an.112.003483.

Wiesmann, N., Kluenker, M., Demuth, P., Brenner, W., Tremel, W., and Brieger, J. 2018. Zinc overload mediated by zinc oxide nanoparticles as innovative anti-tumor agent. Journal of Trace Elements in Medicine and Biology 51:226-234. 